\title{
Effects of pre-harvest chemical application on rice desiccation and seed quality ${ }^{*}$
}

\author{
Yong-qi $\mathrm{HE}^{\S}$, Jin-ping $\mathrm{CHENG}^{\S}$, Liang-feng LIU, Xiao-dan LI, \\ Bin YANG, Hong-sheng ZHANG ${ }^{\dagger \dagger}$, Zhou-fei WANG ${ }^{\dagger \dagger}$ \\ (Laboratory of Seed Science and Technology, State Key Laboratory of Crop Genetics and Germplasm Enhancement / Jiangsu Collaborative \\ Innovation Center for Modern Crop Production, Nanjing Agricultural University, Nanjing 210095, China) \\ †E-mail: hszhang@njau.edu.cn; wzf@njau.edu.cn \\ Received Feb. 1, 2015; Revision accepted May 5, 2015; Crosschecked Sept. 17, 2015
}

\begin{abstract}
Pre-harvest desiccation may increase the efficiency of seed production. Field studies were conducted to determine the effects of diquat, paraquat, and ethephon applications on grain moisture, grain weight, and seed germination of hybrid rice Yanliangyou 88 (Oryza sativa ssp. indica) and conventional rice Wuyunjing 7 (Oryza sativa ssp. japonica). In 2013, we tested 12 treatments applied at four weeks (Yanliangyou 88) and six weeks (Wuyunjing 7) after heading. Results showed that reductions in moisture content were significant two and four days after chemical application. Chemical applications had no adverse effects on 1000-grain weight, germination percentage, or germination index, but there were negative effects on the percentage of normal seedlings. Desiccation effects increased with increase in the period after application, while the effect of ethephon combined with diquat or paraquat on desiccation was limited compared with that of diquat or paraquat alone in a short period after application. In 2013, chemical applications reduced the moisture content by from $0.5 \%$ to $6.4 \%$, the germination percentage by from $0 \%$ to $3.3 \%$, and the percentage of normal seedlings by from $13.3 \%$ to $100.0 \%$. Among the treatments, diquat applied at $120 \mathrm{~g} / \mathrm{ha}$ resulted in effective desiccation with fewer negative effects on grain weight and seed germination in 2013 and 2014. Therefore, diquat may have potential as a pre-harvest chemical desiccation treatment for rice. These results may provide a basis for developing and implementing protocols for large scale field trials.
\end{abstract}

Key words: Chemical desiccant, Rice, Seed desiccation, Seed germination

doi:10.1631/jzus.B1500032 Document code: A CLC number: S511

\section{Introduction}

Rice (Oryza sativa L.) is one of the most important crops in the world. Due to the emphasis placed on early planting and rapid and uniform emergence,

\footnotetext{
¿ Corresponding authors

$\S$ The two authors contributed equally to this work

* Project supported by the Special Fund for Agro-scientific Research in the Public Interest (No. 201203052), the Fundamental Research Funds for the Central Universities (Nos. KYZ201402 and KYZ 201202-9), and the National Natural Science Foundation of China (No. 31271806)

(D) ORCID: Zhou-fei WANG, http://orcid.org/0000-0002-8964-5408

(C) Zhejiang University and Springer-Verlag Berlin Heidelberg 2015
}

the quality of seed production is an important issue in rice (Wang et al., 2010; Cheng et al., 2013). Seed development, maturity, and harvest management are critical considerations for maintaining high seed quality (Bewley et al., 2013). The timing of harvest is a critical step in seed production (Guan et al., 2013). It is necessary to harvest seed at a time as close as possible to physiological maturity, when it reaches its maximum germination and vigor potential (MarcosFilho et al., 1994). Weather conditions at harvest time are frequently unfavorable in subtropical and tropical regions. High temperature and humidity during harvest may cause rice seeds to sprout prematurely (Cheng et al., 2014; Wang et al., 2014). To solve this 
problem, the seeds should be harvested and dried as soon as possible before storage.

Seed drying is a vital operation in the chain of seed handling which permits the early harvest, longterm storage, and high quality production of seed. Due to increasing concerns about energy conservation and jumping energy costs, the high energy cost of seed drying using heating machines needs to be reduced. Harvesting seed with low moisture content (MC) has the dual benefits of saving costs and improving seed quality. When seed has a high MC, it may be damaged by too rapid drying, causing bursting or "case-hardening", in which the surface of the seed dries out rapidly, sealing moisture within the inner layers (K'Opondo, 2011). To solve these issues, leaving seed to dry in fields is a traditional and economical method for farmers. Nevertheless, preharvest chemical desiccation provides some significant advantages. Chemical applications may advance the harvest date, eliminate seed losses, and improve quality without affecting germination (Shafer and Furrer, 1955).

Desiccants, defoliants, and growth regulators are chemicals used in agricultural production to accelerate the preparation of crops for mechanical harvest. For example, diquat (1,1'-ethylene-2,2'-bipyridyl) and paraquat (1,1'-dimethyl-4,4'-bipyridylium dichloride) are non-selective contact herbicides that cause desiccation and defoliation (Hofstra et al., 2001). As herbicides, diquat and paraquat act by inhibiting photosynthesis. They accept electrons from photosystem I and transfer them to molecular oxygen. Diquat and paraquat are then auto-oxidizable, immediately reducing oxygen to superoxide radicals $\left(\mathrm{O}_{2}{ }^{-}\right)$, which may directly or indirectly cause cell death and enhance the drying down of the grain and foliage of crops (Ecobichon, 2001; Esfahani et al., 2012). Ethephon is a plant growth regulator used as a defoliant or desiccant (Ben-Tal, 1987). The application of ethephon to plants releases ethylene that promotes the abscission of different plant organs such as leaves, flowers, and fruits (Hole and Hardwick, 1978). The use of these chemicals in pre-harvest desiccation has been investigated in crops such as soybean (Ratnayake and Shaw, 1992; Ellis et al., 1998), wheat (Clarke, 1981), rapeseed (Esfahani et al., 2012), and rice (Eastin, 1978; 1980; Bond and Bollich, 2007). However, the effects of pre-harvest chemical appli- cations on seed desiccation and quality have not been so thoroughly examined in hybrid indica and conventional japonica rice.

In this study, the effects of pre-harvest diquat, paraquat, and ethephon applications on seed desiccation and quality were investigated using hybrid indica and conventional japonica rice. The MC, grain weight $(\mathrm{GW})$, germination percentage (GP), germination index (GI), and seedling percentage (SP) were evaluated to select the optimal application. Our long-term aim is to understand whether these chemical applications help to reduce the MC of grain, save costs of seed drying, and advance the harvest date of rice, without affecting seed germination.

\section{Materials and methods}

\subsection{Plant and chemical materials}

The hybrid indica rice cultivar Yanliangyou 88 and the conventional japonica rice cultivar Wuyunjing 7 were used in this study. The seed of hybrid Yanliangyou 88 was provided by the Jiangsu Zhongjiang Seed Co., Ltd. (Nanjing, China). Seed of Wuyunjing 7 was provided by the Laboratory of Seed Science and Technology in Nanjing Agricultural University (Nanjing, China). Diquat $(200 \mathrm{~g} / \mathrm{L})$ was provided by the Jiangsu Red Sun Company Group Co., Ltd. (Nanjing, China), and paraquat (200 g/L) and ethephon $(40 \mathrm{~g} / \mathrm{L})$ by the Laboratory of Seed Science and Technology in Nanjing Agricultural University.

\subsection{Field treatments}

Rice seedlings were planted at the Experimental Station of Nanjing Agriculture University (Nanjing, China; $118^{\circ} 50^{\prime} \mathrm{E}, 32^{\circ} 02^{\prime} \mathrm{N}$ ) in 2013 and 2014. Seedlings were planted $17 \mathrm{~cm}$ apart in rows $20 \mathrm{~cm}$ apart and were given standard agronomic management (Cheng et al., 2014). The heading date was recorded as the date when the leading panicle emerged from the leaf sheath (Lu et al., 2011). Twelve chemical treatments and an unsprayed control were compared in 2013 (Table 1). The treatment with the best effects (diquat at $120 \mathrm{~g} / \mathrm{ha}$ ) was repeated in 2014 . Usually, the time from heading to harvest is $25-30 \mathrm{~d}$ for Yanliangyou 88 and 36-44 d for Wuyunjing 7 in Nanjing (China; $118^{\circ} 50^{\prime} \mathrm{E}, 32^{\circ} 02^{\prime} \mathrm{N}$ ). Therefore, treatments were applied at four weeks after heading for 
Yanliangyou 88 and at six weeks after heading for Wuyunjing 7. To ensure uniform spray application, a total of $100 \mathrm{ml}$ of each treatment solution was sprayed on the surfaces of 70 plants from about $20 \mathrm{~cm}$ above the plants. Treatments were applied to Yanliangyou 88 on 19 September 2013 and 22 September 2014, and to Wuyunjing 7 on 11 October 2013 and 14 October 2014. Climatic data were recorded during the period from spraying to seed harvest in both years

Table 1 Field chemical applications to rice in 2013

\begin{tabular}{ll}
\hline Application & \multicolumn{1}{c}{ Active ingredient (g/ha) } \\
\hline $120 \mathrm{D}$ & 120 Diquat \\
$240 \mathrm{D}$ & 240 Diquat \\
$120 \mathrm{D}+24 \mathrm{E}$ & 120 Diquat+24 Ethephon \\
$120 \mathrm{D}+48 \mathrm{E}$ & 120 Diquat+48 Ethephon \\
$240 \mathrm{D}+24 \mathrm{E}$ & 240 Diquat+24 Ethephon \\
$240 \mathrm{D}+48 \mathrm{E}$ & 240 Diquat+48 Ethephon \\
$120 \mathrm{P}$ & 120 Paraquat \\
$240 \mathrm{P}$ & 240 Paraquat \\
$120 \mathrm{P}+24 \mathrm{E}$ & 120 Paraquat+24 Ethephon \\
$120 \mathrm{P}+48 \mathrm{E}$ & 120 Paraquat+48 Ethephon \\
$240 \mathrm{P}+24 \mathrm{E}$ & 240 Paraquat+24 Ethephon \\
$240 \mathrm{P}+48 \mathrm{E}$ & 240 Paraquat+48 Ethephon \\
\hline
\end{tabular}

(Table 2). The weather following chemical applications was warm and sunny to cloudy without rainfall. Seed was harvested two and four days after spraying. There were three replicates of each treatment arranged in a randomized complete block experimental design.

\subsection{Evaluation of moisture content (MC) and grain weight $(\mathrm{GW})$}

Samples of freshly harvested seed (about $250 \mathrm{~g}$ per replicate) were powdered and dried at $104{ }^{\circ} \mathrm{C}$ for $24 \mathrm{~h}$ to determine their MC (Cheng et al., 2013). Other samples of freshly harvested seed were dried at $50{ }^{\circ} \mathrm{C}$ for seven days to evaluate the $1000-\mathrm{GW}$ and to break seed dormancy for further germination evaluation (Jiang et al., 2006). The experiment consisted of three replicates.

\subsection{Evaluation of seed germination}

A total of 50 healthy grains were surfacesterilized with $0.6 \%(6 \mathrm{~g} / \mathrm{L})$ sodium hypochlorite solution for $15 \mathrm{~min}$ and then rinsed three times with sterile distilled water. Seed was then placed in Petri dishes (9 $\mathrm{cm}$ diameter) with two sheets of filter paper, and

Table 2 Weather conditions of the experimental site following chemical applications up to harvest

\begin{tabular}{|c|c|c|c|c|c|c|}
\hline \multirow{2}{*}{ Cultivar } & \multirow{2}{*}{ Operation } & \multirow{2}{*}{ Date } & \multicolumn{3}{|c|}{ Temperature $\left({ }^{\circ} \mathrm{C}\right)$} & \multirow{2}{*}{$\begin{array}{c}\text { Rainfall } \\
(\mathrm{mm})\end{array}$} \\
\hline & & & Max. & Min. & Avg. & \\
\hline \multirow[t]{10}{*}{ Yanliangyou 88} & \multirow[t]{2}{*}{ Spraying } & Sept. 19, 2013 & 30.0 & 21.0 & 25.5 & 0 \\
\hline & & Sept. 20, 2013 & 31.0 & 23.0 & 27.0 & 0 \\
\hline & \multirow[t]{2}{*}{ Seed harvest } & Sept. 21, 2013 & 31.0 & 23.0 & 27.0 & 0 \\
\hline & & Sept. 22, 2013 & 29.0 & 25.0 & 27.0 & 0 \\
\hline & Seed harvest & Sept. 23, 2013 & 30.0 & 20.0 & 25.0 & 0 \\
\hline & \multirow[t]{2}{*}{ Spraying } & Sept. 22, 2014 & 27.0 & 21.0 & 24.0 & 0 \\
\hline & & Sept. 23, 2014 & 24.0 & 20.0 & 22.0 & 0 \\
\hline & \multirow[t]{2}{*}{ Seed harvest } & Sept. 24, 2014 & 27.0 & 19.0 & 23.0 & 0 \\
\hline & & Sept. 25, 2014 & 29.0 & 21.0 & 25.0 & 0 \\
\hline & Seed harvest & Sept. 26, 2014 & 26.0 & 20.0 & 23.0 & 0 \\
\hline \multirow[t]{10}{*}{ Wuyunjing 7} & \multirow[t]{2}{*}{ Spraying } & Oct. 11,2013 & 27.0 & 16.0 & 21.5 & 0 \\
\hline & & Oct. 12,2013 & 28.0 & 17.0 & 22.5 & 0 \\
\hline & \multirow[t]{2}{*}{ Seed harvest } & Oct. 13, 2013 & 28.0 & 16.0 & 22.0 & 0 \\
\hline & & Oct. 14,2013 & 27.0 & 13.0 & 20.0 & 0 \\
\hline & Seed harvest & Oct. 15, 2013 & 15.0 & 8.0 & 11.5 & 0 \\
\hline & \multirow[t]{2}{*}{ Spraying } & Oct. 14, 2014 & 20.0 & 9.0 & 14.5 & 0 \\
\hline & & Oct. 15,2014 & 23.0 & 13.0 & 18.0 & 0 \\
\hline & \multirow[t]{2}{*}{ Seed harvest } & Oct. 16,2014 & 24.0 & 16.0 & 20.0 & 0 \\
\hline & & Oct. 17, 2014 & 24.0 & 15.0 & 19.5 & 0 \\
\hline & Seed harvest & Oct. 18,2014 & 26.0 & 17.0 & 21.5 & 0 \\
\hline
\end{tabular}


$20 \mathrm{ml}$ of distilled water was added. Seed was germinated in a growth chamber at $(30 \pm 1){ }^{\circ} \mathrm{C}$ for $10 \mathrm{~d}$ with a 12-h light/12-h dark photoperiod. They were considered to have germinated when the radical was longer than $2 \mathrm{~mm}$ (Cheng et al., 2014; Wang et al., 2014). The number of germinated seed was counted every day. Then, the GP and GI after $10 \mathrm{~d}$ of germination were calculated using the method described by Wang et al. (2010). $\mathrm{GI}=\sum\left(G_{t} / t\right)$, where $G_{t}$ is the number of the germinated seed on Day $t$. The percentage of normal seedlings (SP) after $10 \mathrm{~d}$ of germination was determined. A seedling was considered to be normal if the length of the shoot had reached at least half the length of the seed and if the length of the root had reached at least grain length. The experiment had three replicates.

\subsection{Data analysis}

Data were analyzed using the analysis of variance (ANOVA) procedure in Statistical Analysis System (SAS 8.0) software, and the differences between applications were compared using a least significant difference (LSD) test at the 1\% probability level.
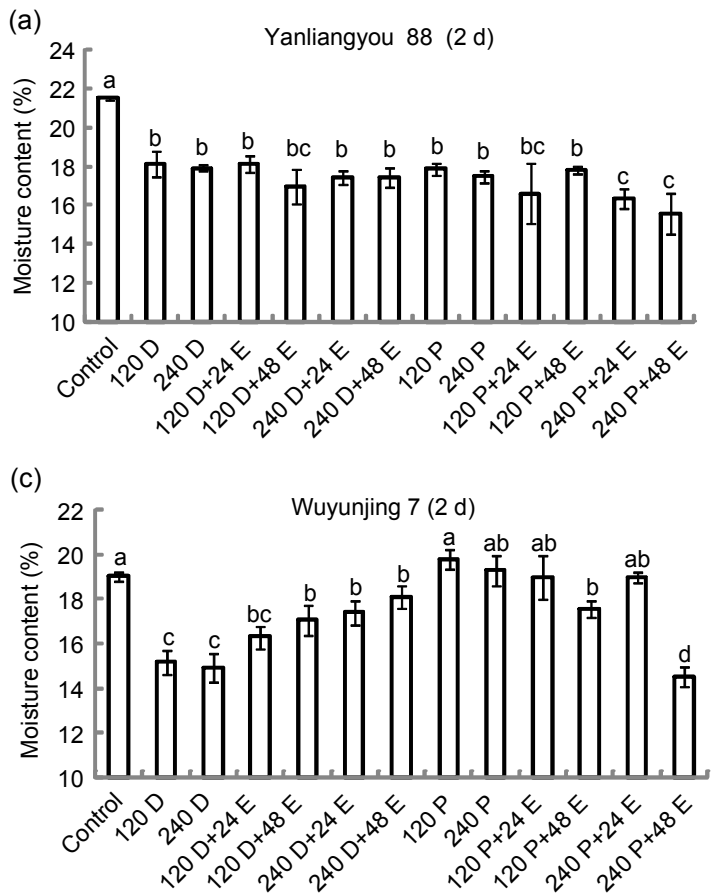

\section{Results}

\subsection{Changes in grain moisture content (MC)}

ANOVA showed a significant effect of chemical applications on MC in $2013(P<0.01$; Fig. 1). Compared with the control, the MC of Yanliangyou 88 was reduced by from $3.4 \%$ to $6.0 \%$ two days after application and by from $3.0 \%$ to $6.4 \%$ four days after application, while the corresponding reductions in the MC of Wuyunjing 7 were from $0 \%$ to $3.9 \%$ and from $0.5 \%$ to $5.0 \%$. The reduction in MC increased with time after application, but no further reductions were observed when diquat and paraquat rates were increased from 120 to $240 \mathrm{~g} / \mathrm{ha}$. There was no significant difference in $\mathrm{MC}$ reduction between diquat and paraquat applications. The effects of chemical applications on MC were more pronounced in Yanliangyou 88 than in Wuyunjing 7. The contribution of ethephon to the effect of diquat or paraquat on desiccation was limited compared with that of diquat or paraquat alone in a short period (two or four days) after application. Only an application of paraquat at $240 \mathrm{~g} / \mathrm{ha}$ with ethephon at $48 \mathrm{~g} / \mathrm{ha}$ resulted in drier
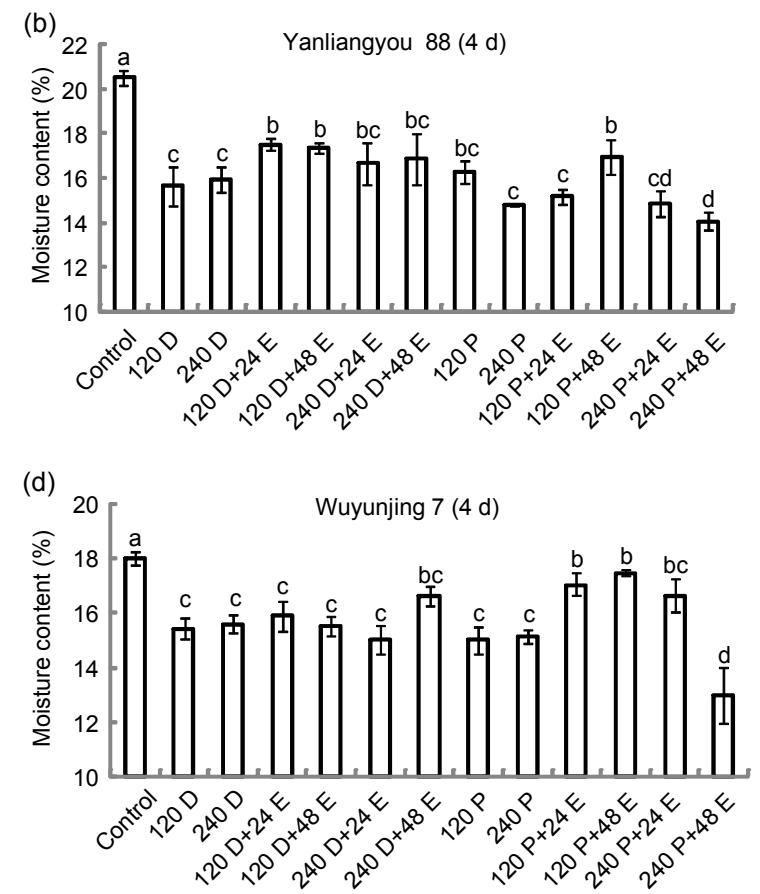

Fig. 1 Mean grain moisture content after chemical applications in 2013

(a) Two days after application to Yanliangyou 88; (b) Four days after application to Yanliangyou 88; (c) Two days after application to Wuyunjing 7; (d) Four days after application to Wuyunjing 7. Different lowercase letters represent significant $(P<0.01)$ differences between applications according to an LSD test; error bars indicate the standard deviation (SD) with $n=3$ 
seed than treatment with paraquat alone in both cultivars. Paraquat at $240 \mathrm{~g} / \mathrm{ha}$ with ethephon at $48 \mathrm{~g} / \mathrm{ha}$ decreased the MC to $15.5 \%$ and $14.1 \%$ in Yanliangyou 88 and to $14.5 \%$ and $13.0 \%$ in Wuyunjing 7 two and four days after application, respectively.

\subsection{Changes in grain weight (GW)}

The GW was not significantly affected by chemical applications in either cultivar in 2013 $(P<0.01$; Fig. 2). The $\mathrm{GW}$ ranged from 21.6 to $22.4 \mathrm{~g}$ and from 21.0 to $22.5 \mathrm{~g}$ in Yanliangyou 88 and from 24.9 to $27.2 \mathrm{~g}$ and 25.8 to $28.4 \mathrm{~g}$ in Wuyunjing 7 , two and four days after application, respectively. The GW decreased slightly when the application rates of diquat and paraquat were increased from 120 to $240 \mathrm{~g} / \mathrm{ha}$, while the application of ethephon with diquat or paraquat did not significantly change GW compared with treatments with diquat or paraquat alone. Paraquat applied at $240 \mathrm{~g} / \mathrm{ha}$ produced the highest GW (22.5 g) in Yanliangyou 88 four days after application, while diquat applied at $240 \mathrm{~g} / \mathrm{ha}$ with $24 \mathrm{~g} / \mathrm{ha}$ ethephon produced the highest GW (28.4 g) in Wuyunjing 7.

\subsection{Changes in seed germination}

The GP was not significantly affected by chemical applications in either cultivar in $2013(P<0.01$; Fig. 3); the GP was more than $96.7 \%$ two and four days after application. The GI of Yanliangyou 88 and Wuyunjing 7 responded differently to the chemical applications in 2013 (Fig. 4). The GI of Yanliangyou 88 ranged from 13.5 to 14.4 and 14.0 to 14.9 two and four days after application, respectively, compared with 12.6 and 14.8 in the corresponding controls. The GI of Wuyunjing 7 ranged from 7.2 to 9.1 and 8.0 to 9.6 two and four days after applications, respectively, compared with 6.7 and 7.6 in the corresponding controls. The application of ethephon with diquat or paraquat increased the GI of Wuyunjing 7 compared with diquat or paraquat treatments alone, but there was no similar effect in Yanliangyou 88. Paraquat at $120 \mathrm{~g} / \mathrm{ha}$ with $24 \mathrm{~g} / \mathrm{ha}$ ethephon produced the highest GI (14.9) in Yanliangyou 88 four days after application, while diquat at $120 \mathrm{~g}$ /ha with $24 \mathrm{~g}$ /ha ethephon produced the highest GI (9.6) in Wuyunjing 7.
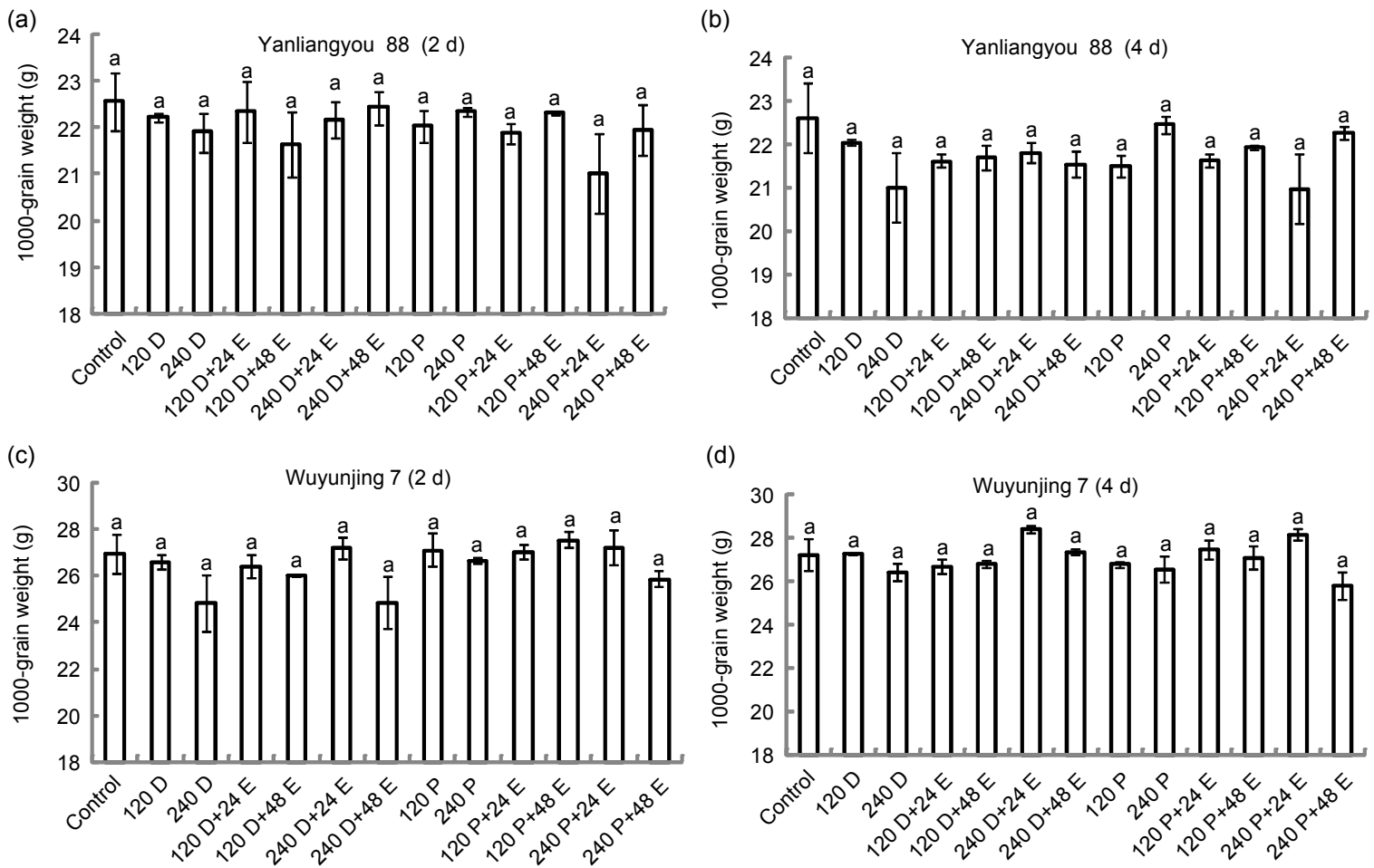

Fig. 2 Mean 1000-grain weight after chemical applications in 2013

(a) Two days after application to Yanliangyou 88; (b) Four days after application to Yanliangyou 88; (c) Two days after application to Wuyunjing 7; (d) Four days after application to Wuyunjing 7. Different lowercase letters represent significant $(P<0.01)$ differences between applications according to an LSD test; error bars indicate the standard deviation (SD) with $n=3$ 

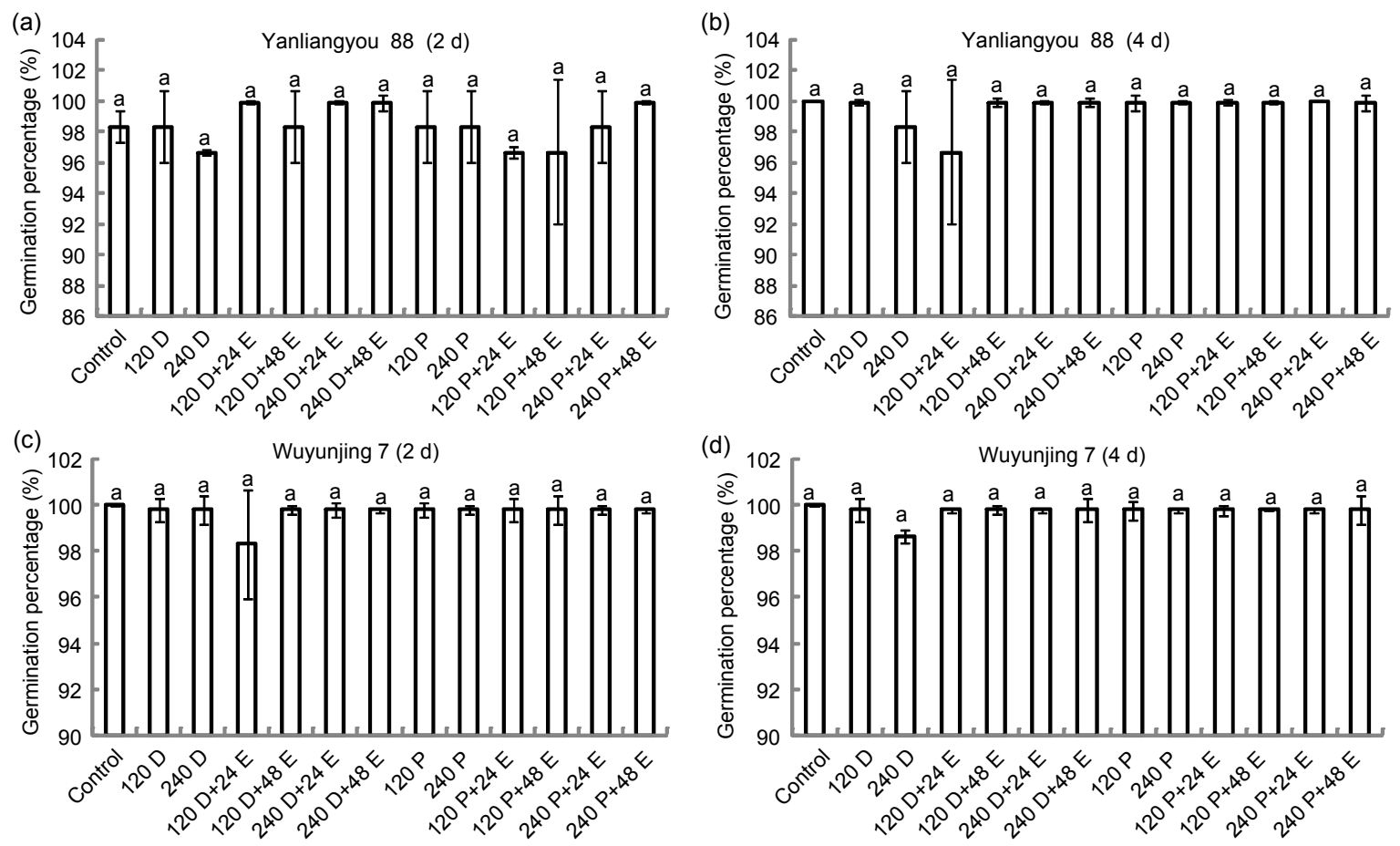

Fig. 3 Mean germination percentage after chemical applications in 2013

(a) Two days after application to Yanliangyou 88; (b) Four days after application to Yanliangyou 88; (c) Two days after application to Wuyunjing 7; (d) Four days after application to Wuyunjing 7. Different lowercase letters represent significant $(P<0.01)$ differences between applications according to an LSD test; error bars indicate the standard deviation (SD) with $n=3$

(a)
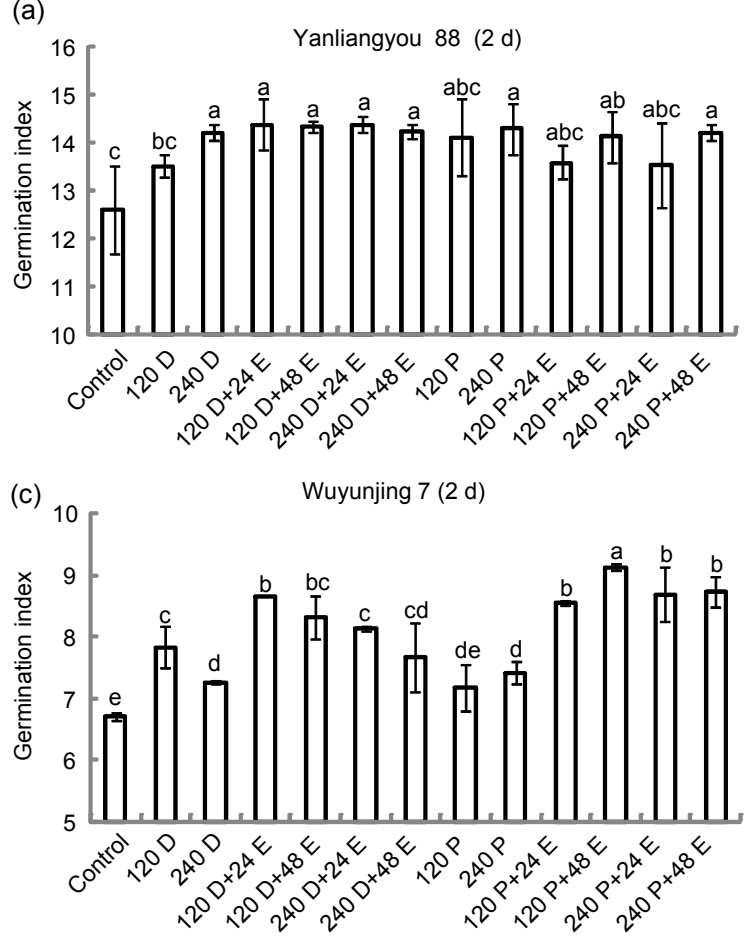
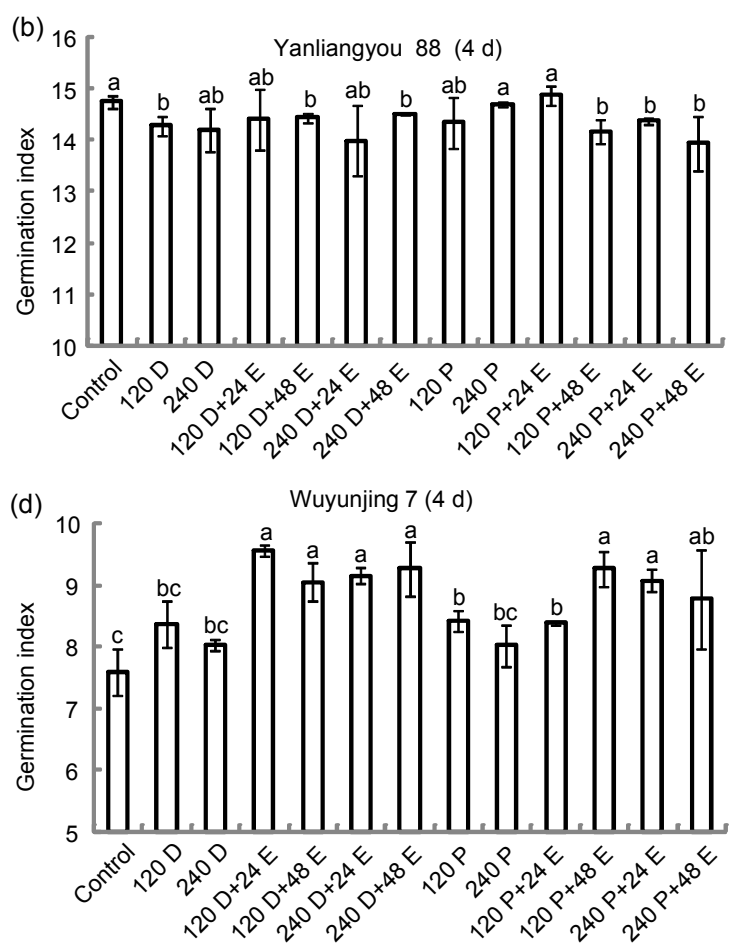

Fig. 4 Mean germination index after chemical applications in 2013

(a) Two days after application to Yanliangyou 88; (b) Four days after application to Yanliangyou 88; (c) Two days after application to Wuyunjing 7; (d) Four days after application to Wuyunjing 7. Different lowercase letters represent significant $(P<0.01)$ differences between applications according to an LSD test; error bars indicate the standard deviation (SD) with $n=3$ 


\subsection{Changes in seedling establishment}

The significant reduction in SP following chemical applications was more obvious in Yanliangyou 88 than in Wuyunjing 7 in $2013(P<0.01$; Fig. 5). Compared with the control, the reduction in SP ranged from $28.3 \%$ to $98.3 \%$ and from $13.3 \%$ to $100 \%$ two and four days, respectively, after application to Yanliangyou 88 , and from $1.7 \%$ to $70.0 \%$ and $0 \%$ to $73.3 \%$, respectively, in Wunyunjing 7 . In contrast, the SP decreased after increasing the rate of application of diquat and paraquat from 120 to $240 \mathrm{~g} / \mathrm{ha}$; the SP was lower following paraquat than following diquat applications. The effects of ethephon with diquat or paraquat on SP were variable between the cultivars. Diquat applied at $120 \mathrm{~g} /$ ha produced the lowest decline in SP in both cultivars in 2013; the SP was $67.5 \%$ and $86.7 \%$ two and four days, respectively, after application in Yanliangyou 88 and $95.0 \%$ and $96.7 \%$, respectively, in Wuyunjing 7 .

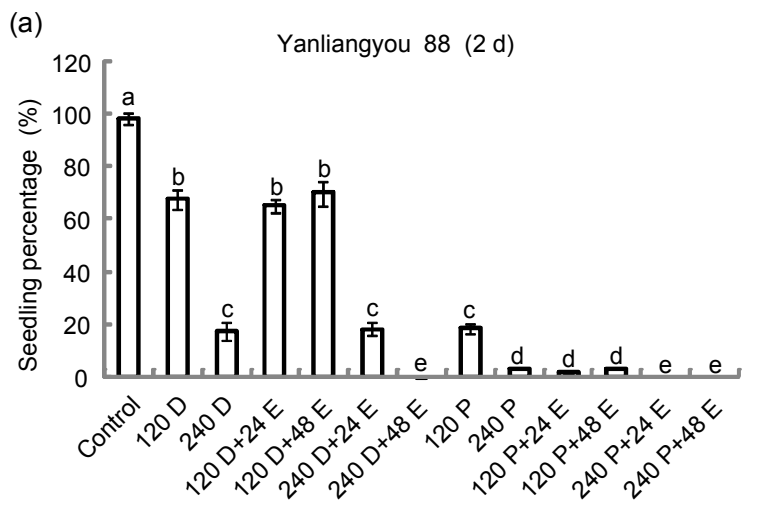

(c)

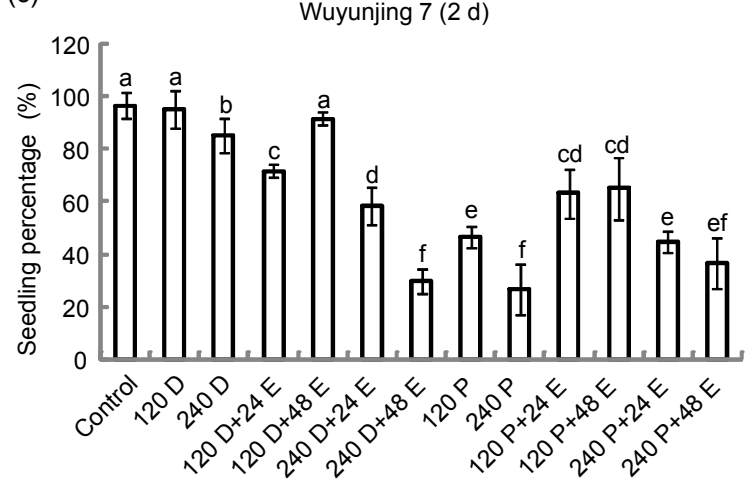

\subsection{Re-evaluation of diquat applied at $120 \mathrm{~g} / \mathrm{ha}$ in 2014}

Considering the traits of MC, GW, GP, GI, and $\mathrm{SP}$ in 2013, diquat applied at $120 \mathrm{~g} /$ ha had the best effects on seed desiccation and quality in both cultivars. Thus, the application of diquat at $120 \mathrm{~g} / \mathrm{ha}$ was repeated in 2014. The MC was significantly reduced by diquat applied at $120 \mathrm{~g} / \mathrm{ha}$ in both cultivars $(P<0.01$; Fig. 6). Compared with the control, the MC was reduced by $4.4 \%$ and $5.1 \%$ two and four days, respectively, after application in Yanliangyou 88, and $2.8 \%$ and $1.7 \%$, respectively, in Wuyunjing 7 . Diquat applied at $120 \mathrm{~g} /$ ha did not significantly decrease GW and GP $(P<0.01$; Figs. 6 and 7). Moreover, the GI was significantly increased by diquat applied at $120 \mathrm{~g} / \mathrm{ha}$, but the SP was significantly reduced ( $P<0.01$; Fig. 7). Diquat applied at $120 \mathrm{~g} / \mathrm{ha}$ could accelerate foliar desiccation, improve the uniformity of grain color, and advance harvest date (Fig. 8).
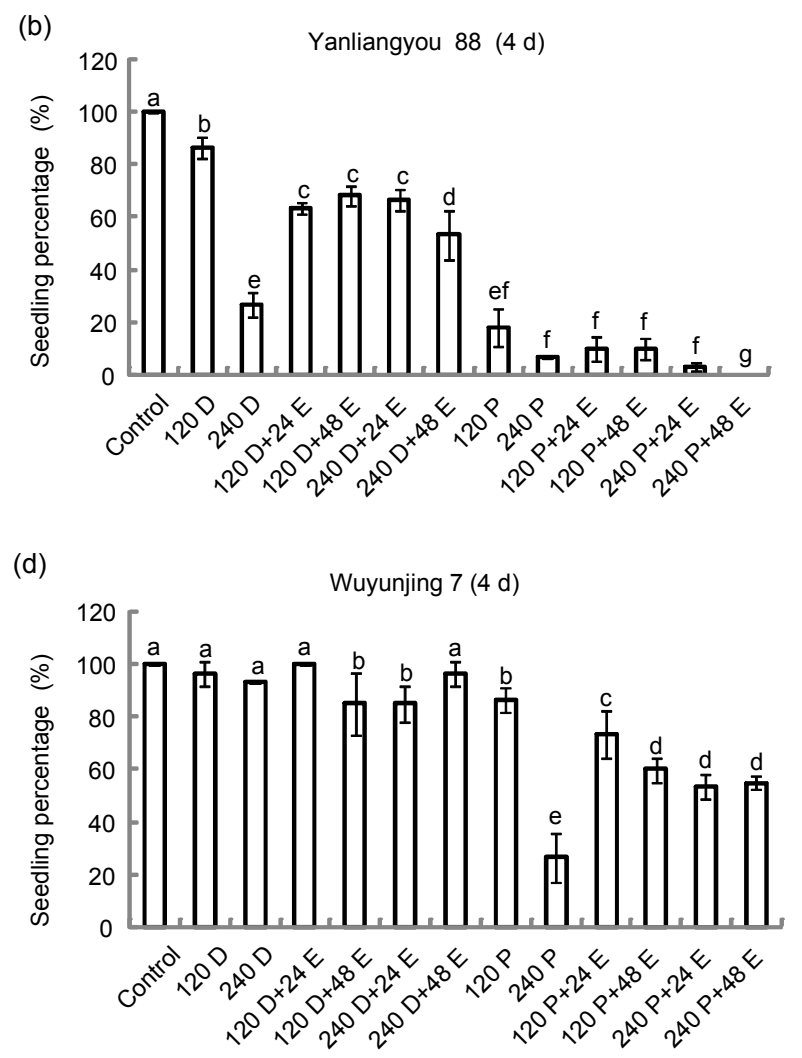

Fig. 5 Mean seedling percentage after chemical applications in 2013

(a) Two days after application to Yanliangyou 88; (b) Four days after application to Yanliangyou 88; (c) Two days after application to Wuyunjing 7; (d) Four days after application to Wuyunjing 7. Different lowercase letters represent significant $(P<0.01)$ differences between applications according to an LSD test; error bars indicate the standard deviation (SD) with $n=3$ 

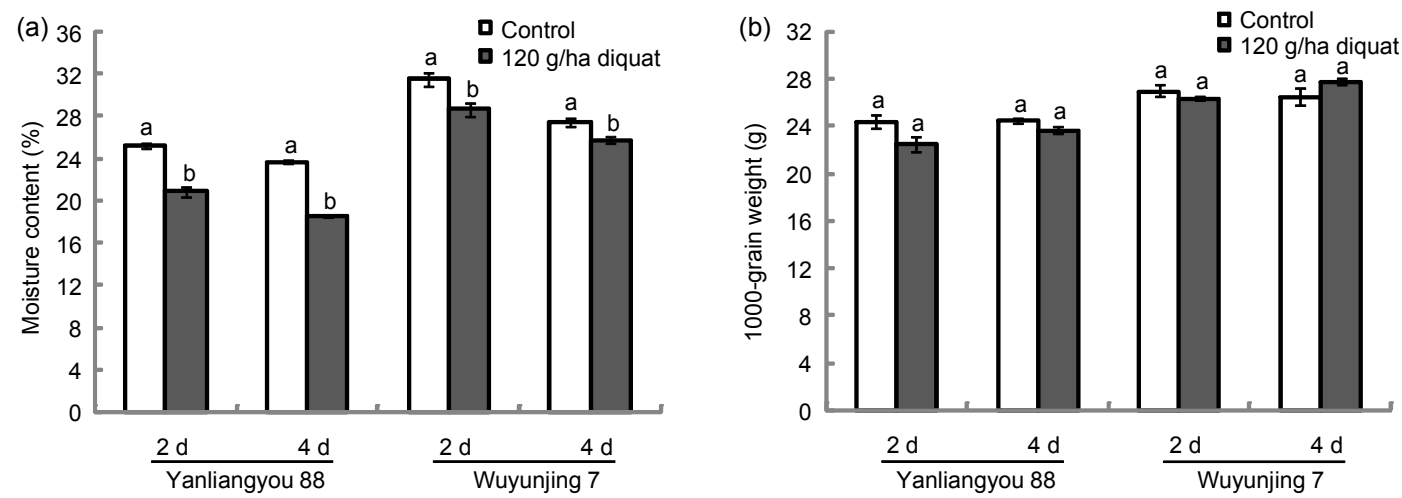

Fig. 6 Mean moisture content and grain weight after application of diquat at $120 \mathrm{~g} / \mathrm{ha}$ in 2014

(a) Moisture content two and four days after application; (b) 1000-grain weight two and four days after application. Different lowercase letters represent significant $(P<0.01)$ differences between control and application according to an LSD test; error bars indicate the standard deviation (SD) with $n=3$
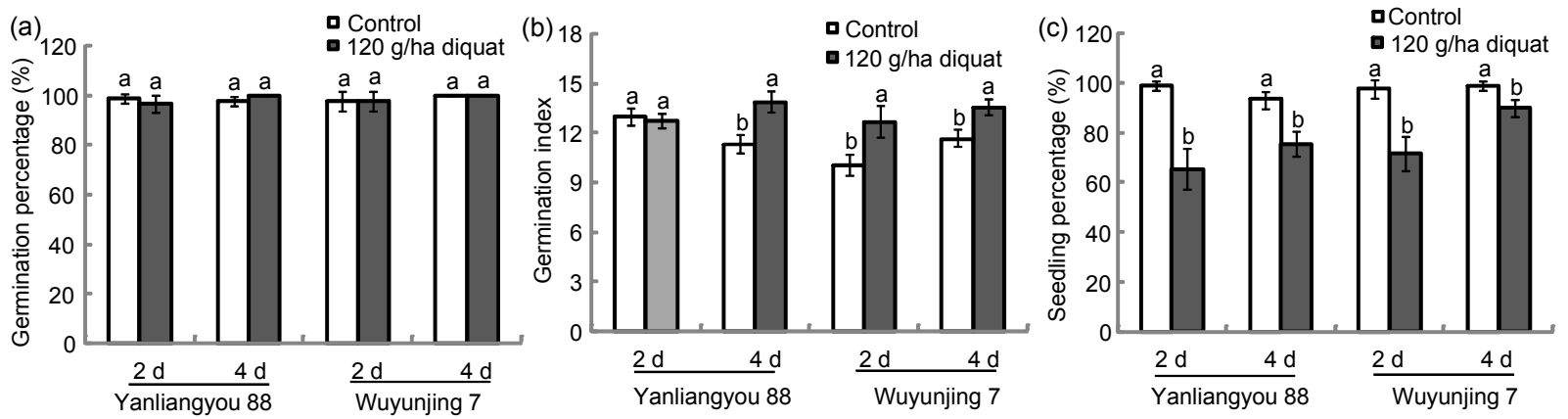

Fig. 7 Mean seed germination and seedling percentage after application of diquat at $120 \mathrm{~g} / \mathrm{ha}$ in 2014

(a) Germination percentage two and four days after application; (b) Germination index two and four days after application; (c) Seedling percentage two and four days after application. Different lowercase letters represent significant $(P<0.01)$ differences between control and application according to an LSD test; error bars indicate the standard deviation (SD) with $n=3$

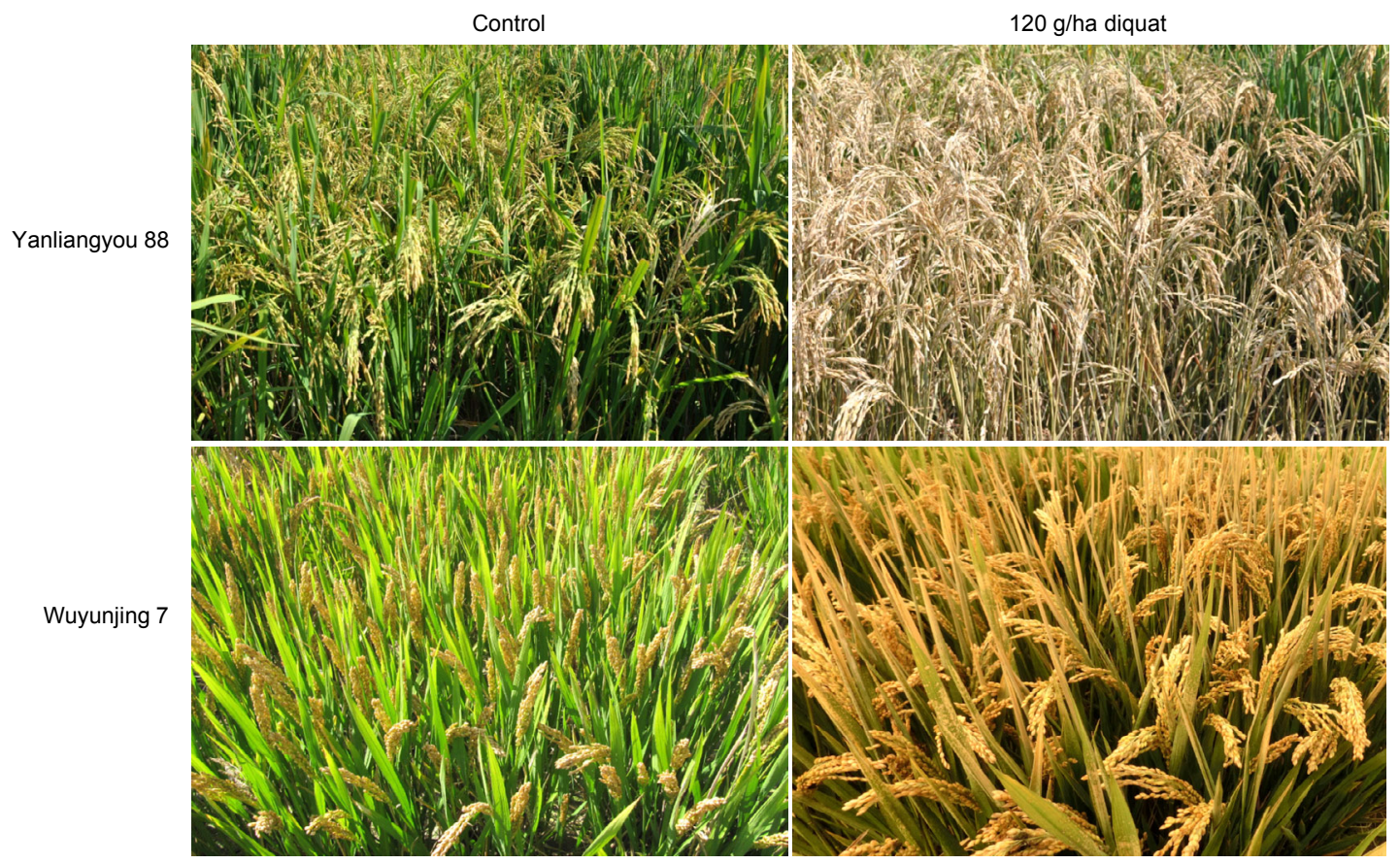

Fig. 8 Field performance two days after application of diquat at $120 \mathrm{~g} / \mathrm{ha}$ in 2014 


\section{Discussion}

Chemicals for field crop desiccation are classified into two main groups: those with a rapid killing action $(24$ to $72 \mathrm{~h}$ ) and those with slower action, requiring 7 to $10 \mathrm{~d}$ between application and harvest (Shafer and Furrer, 1955). In this study, based on their $\mathrm{MC}$ and color, the seed could be harvested two days after chemical application. This suggests that the diquat, paraquat, and diquat or paraquat with ethephon treatments cause rapid desiccation. However, a somewhat longer period from application to harvest ( $>4 \mathrm{~d}$ ) is needed for the MC of rice to reach about $15 \%$ in fields. The rate of seed desiccation depends on seed size and composition, speed of surface evaporation, temperature, initial moisture level, and seed coat permeability. In this study, chemical desiccation was better in indica Yanliangyou 88 than in japonica Wuyunjing 7. Possible reasons are that seed of Yanliangyou 88 may have better permeability, and that the temperature may have been higher during treatments applied to Yanliangyou 88 .

In this study, the value of chemical application was tested in two ways: desiccation and defoliation. The desiccants diquat and paraquat have been proved to be the most effective seed desiccation agents. Ethephon inside the leaf releases ethylene, a powerful and natural defoliant (Burg, 1968; Osborne, 1968). Our results showed that the $\mathrm{MC}$ showed no significant further decrease two or four days after application when the dose of diquat and paraquat was increased in 2013, presumably because there was too short a period from application to harvest in this study. Similarly, diquat at $1120 \mathrm{~g} / \mathrm{ha}$ did not appreciably accelerate desiccation of spinach, table beet, or coriander compared with a $560 \mathrm{~g} / \mathrm{ha}$ rate (Miller, 2002). Therefore, diquat and paraquat applied at $120 \mathrm{~g} / \mathrm{ha}$ for a short period (two to four days) was adequate for rice desiccation in this study. The effect of ethephon with diquat or paraquat on desiccation was limited compared with that of diquat or paraquat alone. Possible reasons might be that there was too short a period from application to harvest or that the doses of ethephon were too low in this study. Hole and Hardwick (1978) showed that ethephon applied at $1000 \mathrm{~g} / \mathrm{ha}$ is effective in reducing moisture in beans. This suggests that the application dose and harvest time after application are important for chemical desiccation.
Eastin (1980) reported that in rice, paraquat alone at $140 \mathrm{~g} /$ ha applied seven days pre-harvest reduced MC compared with the control with $18.5 \% \mathrm{MC}$. Bond and Bollich (2007) indicated that the largest differences in MC between desiccant treatments and a non-treated control were no greater than $1.8 \%$ in several studies. In this study in 2013, the MC was reduced by from $0.5 \%$ to $6.4 \%$ compared with the control when chemicals were applied to rice with about $20 \%$ moisture (data not shown). The application of diquat at 120 and $240 \mathrm{~g} / \mathrm{ha}$ and paraquat at $240 \mathrm{~g} / \mathrm{ha}$ with ethephon at $48 \mathrm{~g} / \mathrm{ha}$ produced a greater desiccation effect two and four days after application in 2013. In particular, the application of paraquat at $240 \mathrm{~g} / \mathrm{ha}$ with ethephon at $48 \mathrm{~g} / \mathrm{ha}$ reduced $\mathrm{MC}$ by from $4.3 \%$ to $6.4 \%$ compared with the control. Thus, diquat, paraquat, and ethephon can be effective desiccants for rice.

A chemical desiccant that reduces seed moisture while not lowering seed yield or germination would be an excellent option for rice. Eastin (1978) showed that paraquat applied to rice at doses up to $560 \mathrm{~g} / \mathrm{ha}$ at $10 \mathrm{~d}$ pre-harvest had no negative effects on rough rice or head rice yields. However, Eastin (1980) observed that head rice yield was reduced when diquat (280 or $560 \mathrm{~g} / \mathrm{ha}$ ) and paraquat (140 g/ha) were applied seven days pre-harvest to rice with a grain MC of $25 \%$. Bond and Bollich (2007) indicated that the effects of pre-harvest desiccants on rice yield depended on the dose, application timing, and cultivar used. In this study in 2013, we found that the 1000-GW of rice was not significantly reduced when diquat (120 or $240 \mathrm{~g} / \mathrm{ha}$ ), paraquat (120 or $240 \mathrm{~g} / \mathrm{ha}$ ) alone or combined with ethephon ( 24 or $48 \mathrm{~g} / \mathrm{ha}$ ) were applied at the maturity stage when grain MC was about $20 \%$. This suggests that the greatest yield potential for rice chemical desiccation may be achievable at the preharvest stage.

The potential for reduced seed germination is a concern when chemicals are applied in seed production. Crop seeds react differently to chemical applications: a reduction in seed germination may occur if applications are made at the wrong dose or time. For example, Roberts and Griffiths (1973) observed that application of diquat to perennial ryegrass (Lolium perenne L.) reduced seed germination and increased the frequency of abnormal seedlings. However, Moyer et al. (1996) showed that diquat applied to alfalfa 
was not detrimental to seed germination. Miller (2002) indicated that diquat did not significantly reduce seed germination of spinach, table beet, or coriander unless rates in excess of $560 \mathrm{~g} / \mathrm{ha}$ were used. Bennett and Shaw (2000) showed that reductions in germination, emergence, and seedling growth occurred in soybean when desiccant was applied in the beginning seed (R5) or full seed (R6) growth stages. GP is an estimate of the viability of a population of seeds, and GI is an estimate of the speed and uniformity of germination (Wang et al., 2010; 2011). In this study, the chemicals did not significantly reduce GP or GI when applied in 2013 to rice with an MC of about $20 \%$. The GI was improved by chemical applications, especially in japonica Wuyunjing 7, presumably because they improved the level of seed maturity. However, reductions in SP were observed following several chemical applications. The SP in seeds harvested four days after application was much better than that in seeds harvested two days after application. This might have been due to a reduction in chemical residues on seed surfaces with increasing days from application to harvest. Diquat applied at $120 \mathrm{~g} / \mathrm{ha}$ had the best SP in both Yanliangyou $88(\mathrm{SP}=86.7 \%)$ and Wuyunjing 7 $(\mathrm{SP}=96.7 \%)$ four days after application in 2013.

The results of chemical application on the MC, GW, GP, GI, and SP in 2013 suggested that diquat applied at $120 \mathrm{~g} / \mathrm{ha}$ has potential for use in rice pre-harvest desiccation. Thus, the application of diquat at $120 \mathrm{~g} /$ ha was repeated in 2014. As in 2013, the $\mathrm{MC}$ and SP were significantly decreased after application of diquat at $120 \mathrm{~g} / \mathrm{ha}$, and there were no adverse effects on GW, GP, or GI. Our results indicated that the performance of SP was unacceptable after application of diquat at $120 \mathrm{~g}$ /ha in 2014; SP was $75.5 \%$ and $90.0 \%$ four days after application for Yanliangyou 88 and Wuyunjing 7, respectively. The possible reason is that the treatment was applied to rice with a higher MC in 2014 than in 2013; the MC was about $20 \%$ for both of Yanliangyou 88 and Wuyunjing 7 in 2013, and about $25 \%$ and $30 \%$, respectively, in 2014. Protocols for diquat application, including the dose, application timing, and harvest date need to be further studied using different rice cultivars over several years.

In conclusion, the chemical agents (diquat, paraquat, and ethephon) produced rapid desiccation which may permit rice to be harvested as soon as two to four days after application when warm and dry conditions prevail. The chemical applications did not affect seed germination but did inhibit seedling growth. Our results suggest that diquat at $120 \mathrm{~g} / \mathrm{ha}$ may be applied as a pre-harvest desiccation treatment for rice. Further experiments should focus on the effects of a lower dose of diquat on grain desiccation, yield, and quality in rice and other crops. Our results may provide a basis for developing and implementing protocols in large scale field trials.

\section{Compliance with ethics guidelines}

Yong-qi HE, Jin-ping CHENG, Liang-feng LIU, Xiaodan LI, Bin YANG, Hong-sheng ZHANG, and Zhou-fei WANG declare that they have no conflict of interest.

This article does not contain any studies with human or animal subjects performed by any of the authors.

\section{References}

Bennett, A.C., Shaw, D.R., 2000. Effect of preharvest desiccants on group IV Glycine max seed viability. Weed Sci., 48(4):426-430. [doi:10.1614/0043-1745(2000)048[0426: EOPDOG]2.0.CO;2]

Ben-Tal, Y., 1987. Improving ethephon's effect on olive fruit drop by glycerine. In: Reid, M.S. (Ed.), Manipulation of Ethylene Responses in Horticulture, XXII IHC. ISHS Acta Hortic. 201, California, p.117-123. [doi:10.17660/ ActaHortic.1987.201.10]

Bewley, D.J., Bradford, K., Hillorst, H., et al., 2013. Seeds: Physiology of Development, Germination and Dormancy, 3rd Ed. Springer, New York. [doi:10.1007/978-1-46144693-4]

Bond, J.A., Bollich, P.K., 2007. Effects of pre-harvest desiccants on rice yield and quality. Crop Prot., 26(4):490-494. [doi:10.1016/j.cropro.2006.02.017]

Burg, S.P., 1968. Ethylene, plant senescence and abscission. Plant Physiol., 43(9):1503-1511.

Cheng, J., Wang, L., Du, W., et al., 2014. Dynamic quantitative trait locus analysis of seed dormancy at three development stages in rice. Mol. Breeding, 34(2):501-510. [doi:10.1007/s11032-014-0053-z]

Cheng, X., Cheng, J., Huang, X., et al., 2013. Dynamic quantitative trait loci analysis of seed reserve utilization during three germination stages in rice. PLoS ONE, 8(11): e80002. [doi:10.1371/journal.pone.0080002]

Clarke, J.M., 1981. Effect of diquat, paraquat and glyphosate on preharvest drying of wheat. Can. J. Plant Sci., 61(4): 909-913. [doi:10.4141/cjps81-135]

Eastin, E.F., 1978. Preharvest desiccation of rice with paraquat. Crop Sci., 18(6):1068-1070. [doi:10.2135/cropsci1978. 0011183X001800060041x]

Eastin, E.F., 1980. Preharvest desiccants for rice. Crop Sci., 20(3):389-391. [doi:10.2135/cropsci1980.0011183X002 $000030027 \mathrm{x}$ ] 
Ecobichon, D., 2001. Toxic effects of pesticides. In: Klaassen, C.D. (Ed.), Casarett and Doull's Toxicology, 6th Ed. McGraw-Hill, New York, p.763-810.

Ellis, J.M., Shaw, D.R., Barrentine, W.L., 1998. Herbicide combinations for preharvest weed desiccation in early maturing soybean (Glycine max). Weed Technol., 12(1): 157-165.

Esfahani, M., Fardi, M., Asghari, J., et al., 2012. Effects of pre-harvest application of parquat on grain moisture reduction, grain yield and quality of rapeseed (Brassica napus L.) cultivars. Caspian J. Environ. Sci., 10(1):75-82.

Guan, Y.J., Hu, J., Wang, Z.F., et al., 2013. Time series regression analysis between changes in kernel size and seed vigor during developmental stage of sh2 sweet corn (Zea mays L.) seeds. Sci. Hortic., 154:25-30. [doi:10.1016/j. scienta.2013.02.016]

Hofstra, D.E., Clayton, J.S., Getsinger, K.D., 2001. Evaluation of selected herbicides for the control of exotic submerged weeds in New Zealand: II. The effects of turbidity on diquat and endothall efficacy. J. Aquat. Plant Manage, 39:25-27.

Hole, C.C., Hardwick, R.C., 1978. Chemical aids to drying seeds of beans (Phaseolus vulgaris) before harvest. Ann. Appl. Biol., 88(3):421-427. [doi:10.1111/j.1744-7348. 1978.tb00734.x]

Jiang, L., Liu, S.J., Hou, M.Y., et al., 2006. Analysis of QTLs for seed low temperature germinability and anoxia germinability in rice (Oryza sativa L.). Field Crops Res., 98(1):68-75. [doi:10.1016/j.fcr.2005.12.015]

K'Opondo, F.B.O., 2011. Influence of drying method and fruit position on the mother plant on seed quality of spiderplant (Cleome gynandra L.) morphotypes from western Kenya. Adv. Appl. Sci. Res., 2(3):74-83.

Lu, B., Xie, K., Yang, C., et al., 2011. Mapping two major effect grain dormancy QTL in rice. Mol. Breeding, 28(4): 453-462. [doi:10.1007/s11032-010-9495-0]

Marcos-Filho, J., Chamma, H.M.C.P., Casagrande, J.R.R., et al., 1994. Effect of harvesting time on seed physiological quality, chemical composition and storability of soybeans. Sci. Agric., 51(2):298-304. [doi:10.1590/ S0103-90161994000200016]

Miller, T.W., 2002. Diquat used as a preharvest desiccant affects seed germination of spinach, table beet, and coriander. HortScience, 37(7):1032-1034.

Moyer, J.R., Acharya, S.N., Fraser, J., et al., 1996. Desiccation of alfalfa for seed production with diquat and glufosinate. Can. J. Plant Sci., 76(3):435-439. [doi:10.4141/cjps96077]

Osborne, D.J., 1968. Defoliation and defoliants. Nature, 219(5154):564-567. [doi:10.1038/219564a0]

Ratnayake, S., Shaw, D.R., 1992. Effects of harvest-aid herbicides on soybean (Glycine max) seed yield and quality. Weed Technol., 6(2):339-344.

Roberts, H.M., Griffiths, D.J., 1973. Pre-harvest desiccation of herbage seed crops and its effect on seed quality. Grass
Forage Sci., 28(4):189-192. [doi:10.1111/j.1365-2494. 1973.tb00744.x]

Shafer, N.E., Furrer, J.D., 1955. Chemical drying sprays as an aid for seed production. Historical Materials from University of Nebraska-Lincoln Extension. Paper 3073. Available from http://digitalcommons.unl.edu/extension hist $/ 3073$

Wang, L., Cheng, J., Lai, Y., et al., 2014. Identification of QTLs with additive, epistatic and QTL $\times$ development interaction effects for seed dormancy in rice. Planta, 239(2):411-420. [doi:10.1007/s00425-013-1991-0]

Wang, Z.F., Wang, J.F., Bao, Y.M., et al., 2010. Quantitative trait loci analysis for rice seed vigor during the germination stage. J. Zhejiang Univ.-Sci. B (Biomed. \& Biotechnol.), 11(12):958-964. [doi:10.1631/jzus.B1000238]

Wang, Z.F., Wang, J.F., Bao, Y.M., et al., 2011. Quantitative trait loci controlling rice seed germination under salt stress. Euphytica, 178(3):297-307. [doi:10.1007/s10681010-0287-8]

\section{中文概要}

题 目: 收获前化学脱水剂处理对水稻种子干燥及质量的 影响

目 的: 節选适宜于水稻收获前田间种子快速干燥处理的 试剂和方法, 为大规模种子生产过程中降低种子 干燥成本、提早种子收获及确保种子质量提供基 础。

创新点: 明确了敌草快、百草枯和乙烯利化学脱水剂处理, 对杂交籼稻和常规粳稻种子干燥、粒重及发芽的 影响, 成功篮选出适宜于水稻生产的化学脱水剂 敌草快。

方 法: 利用不同浓度敌草快、百草枯、乙烯利等配制的 化学脱水剂, 对抽穗后第 4 周的杂交籼稻盐两优 88 和抽穗后第 6 周的常规粳稻武运粳 7 号分别进 行喷施。其中， 2013 年采用了 12 种不同浓度的 试剂处理, 以未喷施试剂为空白对照, 2014 年对 前一年试验中表现效果最好的处理 $(120 \mathrm{~g} / \mathrm{ha}$ 敌 草快)进行重复验证。处理后 $2 \mathrm{~d}$ 和 $4 \mathrm{~d}$ 收获种子, 测定种子含水量 (MC) 、粒重 $(\mathrm{GW})$ 、发芽率 (GR)、发芽指数 (GI) 和成苗率 (SP) 等指 标。

结 论: 对水稻喷施不同化学脱水剂 $2 \mathrm{~d}$ 和 $4 \mathrm{~d}$ 后, 与对照 相比, 种子 $\mathrm{MC}$ 和 SP 显著降低 (图 1 和 5), 但 未影响 GW、GR 和 GI（图 2 4)。结合两年试 验结果发现, 喷施 $120 \mathrm{~g} / \mathrm{ha}$ 敌草快具有较好的种 子干燥效果, 喷施后对种子粒重、发芽和成苗等 影响较小（图 6 8)。因此, 敌草快可以作为水 稻收获前种子干燥脱水剂, 具有潜在的应用价 值。研究结果为今后进一步开展水稻大规模田间 种子脱水干燥处理提供基础。

关键词: 水稻; 化学脱水剂; 种子干燥; 种子发芽 